\title{
Leachate of Demolition Waste
}

\author{
Yatnanta Padma Devia ${ }^{1, *}$, Eko Andi Suryo ${ }^{1}$ \\ ${ }^{1}$ Department of Civil Engineering, Brawijaya University, Jl Mayjen Haryono 167 Malang, Indonesia
}

\begin{abstract}
Demolition waste contains not only non-hazardous and uncontaminated material but also consists a small fraction of residual hazardous materials that need to be separated, processed or disposed of. The demolition wastes are utilized as aggregates in new concrete and road construction application, initial resources in reuse construction and disposal materials of landfill. When demolition wastes are disposed in unprotected landfills can cause environmental and health problems as leaching that may have consequence in groundwater and soil. The majority of demolition wastes researches in Indonesia addressed its classification, quantification and causes, while environmental effect do not explore yet. Therefore, it is necessary to investigate demolition waste in Indonesia especially its leaching effects. This preliminary research is showing result of leaching test of demolition waste using toxicity characteristic leaching procedure on copper, zinc, lead, sulphate, chloride and fluoride. A concentration of lead showed in higher level $(0.65 \mathrm{mg} / \mathrm{L})$ than Indonesian standard of toxicity characteristic leaching procedure $(0.50 \mathrm{mg} / \mathrm{L})$. Some elements were detected reach near and over the limit value of drinking water standard, such as sulphate and fluoride. Sorting is better to do to minimize the risk of hazardous waste from demolition waste.
\end{abstract}

\section{Introduction}

Demolition waste defined as waste debris from destruction of a construction [1] as a part of construction and demolition waste (CDW), which the waste arises from construction, renovation and demolition activities [2]. In Indonesia, demolition waste is classified into two categories, called valuable waste and non-valuable waste [3]. Generally, valuable waste is reuse or re-sale, such as wood, roof tile, steel or other metals. A non-valuable waste, such as inert waste (concrete, brick masonry, sand, gravel) utilize as aggregate in new concrete, road construction application (Fig. 1), a virgin resources in reuse construction (Fig. 2) and disposal material of landfill [4]. A large quantities of demolition waste that produced from buildings and civil engineering works demolition are landfilled without pre-treatment after separation of valuable waste for reuse and recycling [5]. Furthermore, demolition waste contains not only non-hazardous and uncontaminated material but also consists a small fraction of residual hazardous materials that need to be separated, processed or disposed of [6]. When demolition waste is disposed in un-protected

\footnotetext{
* Corresponding author: ypadmad@gmail.com
} 
landfills can cause health and environmental problems as leaching that may result in waterborne contaminant potentially affecting subsoil and groundwater [4, 7]. Mostly the previous studies, especially in Indonesia, focussed on classification, quantification and cause of demolition waste [3,8], but in the contrary its environmental effects still not explore yet. This study objective is to investigate leachate of demolition waste.

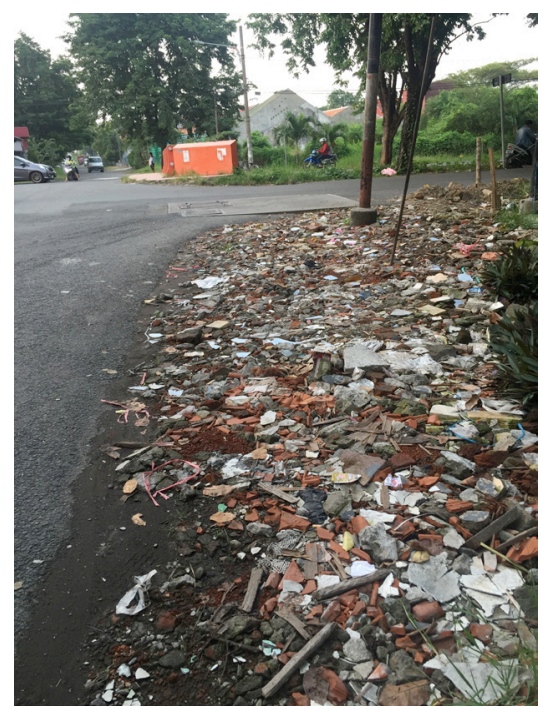

Fig. 1. Demolition waste for road construction

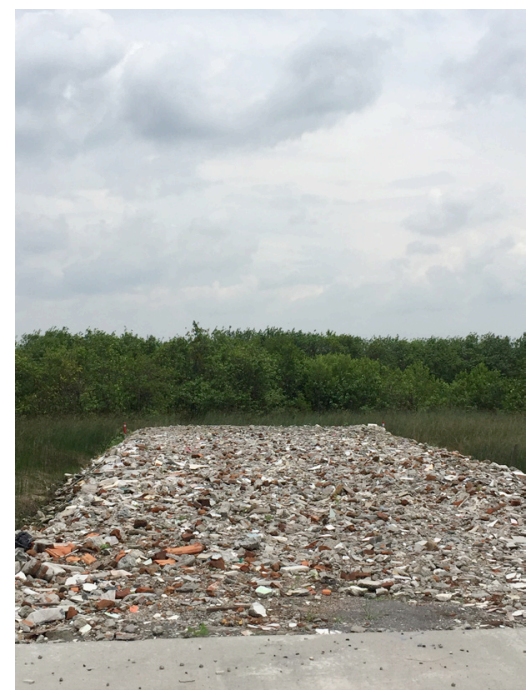

Fig. 2. Demolition waste for reuse construction

\section{Methods}

\subsection{Quantification of demolition waste used for test}

A complexity of demolition waste in type, age, activity, site and properties made uneasy quantification of sample obtained [7, 9]. In developing countries, such as Indonesia, information of generation of demolition waste is less than construction waste due to manual method applied more than blasting methods [10]. Quantification construction and demolition waste (CDW), according to $\mathrm{Wu}$ et al. [10], were site visit method, waste generation rate method, lifetime analysis method, classification system accumulation method, variables modeling method [11] and other particular methods. Ten samples were taken from demolition building site, which half of them from building in the age of less than 10 years and in other half its more than 10 years. However, a suitable portion of sample for leaching test that represent demolition waste in a site were not available on previous studies especially in Indonesia. A simple method of sampling that referred to Trankler [9], was used in this experiment. Each sample during demolition days was taken around $1 \%$ of day's waste. This sample was mixed divided to obtain sample that meet standard agitation test of toxicity characteristic leaching procedure. The particle size range of $0-8 \mathrm{~mm}$ or categorized as fine fraction was chosen because higher size will less endanger environment by its leachate [9]. 


\subsection{Toxicity Characteristic Leaching Procedure for demolition waste}

Samples of demolition waste from houses demolition in Surabaya City, Indonesia were collected and the Figure as shown in Fig. 3. Samples were categorized in their construction year or age of the house which less and more than 10 years. Samples were taken for the determination of the standard agitation test by using rotary agitator. The leachate was analysed according to toxicity characteristic leaching procedure (TCLP). The copper ( $\mathrm{Cu}$ ), lead $(\mathrm{Pb})$, zinc $(\mathrm{Zn})$, sulphate $\left(\mathrm{SO}_{4}\right)$, chloride $\left(\mathrm{Cl}^{-}\right)$and fluoride $(\mathrm{F})$ content were determined by referring to the standard methods [12] using a atomic absorption spectroscopy for $\mathrm{Cu}$, $\mathrm{Pb}$ and $\mathrm{Zn}$; a spectrophotometry for $\mathrm{SO}_{4}$ and $\mathrm{F}$; and an argentometry method for $\mathrm{Cl}$.

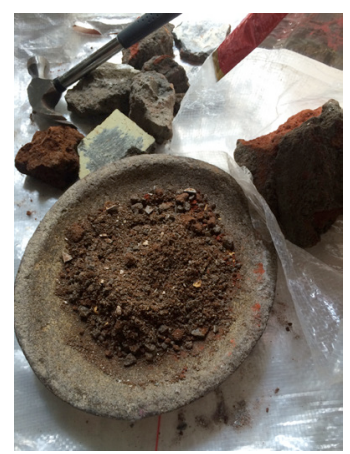

Fig. 3. Sample of demolition waste

\section{Results and Discussion}

Quantification of demolition waste sample summarizes in weight percentage that consist of inert waste and source of hazardous waste, such as asbestos and paint. Table 1 summarizes demolition waste in weight percentage to the total quantity of demolition waste.

Table 1. Weight percentage of demolition waste sample

\begin{tabular}{|c|c|}
\hline Demolition waste & \% mass \\
\hline Brick masonry & 54 \\
\hline Concrete & 35 \\
\hline Cement & 7 \\
\hline Asbestos & 2 \\
\hline Ceramic & 3 \\
\hline Paint & 0.2 \\
\hline
\end{tabular}

Six elements were analyzed: copper $(\mathrm{Cu})$, lead $(\mathrm{Pb})$, zinc $(\mathrm{Zn})$, sulphate $\left(\mathrm{SO}_{4}\right)$, chloride $(\mathrm{Cl})$ and fluoride $(\mathrm{F})$. In a comparison, Table 2 shows leachate concentration of samples at minimum/maximum values and leaching limit values for the acceptance of waste of the Indonesia TCLP standard by regulation PP RI no 101/2014 Appendix IV Standard TCLP Test. Copper, zinc, sulphate, chloride and fluoride were detected in considerable levels on both samples of demolition wastes which represent waste of less than (samples N1 - N5) 
and more than 10 years (samples O1 - O5). Similarly, a limit value of copper, zinc, sulphate, chloride and fluoride of European Council Decision (2003/33/CE) that used by Roussat et al. [7] on their leaching concentration from the percolation test were 0.6, 1.2, 1500,460 and $2.5 \mathrm{mg} / \mathrm{L}$, respectively. Based on their values, copper, zinc, sulphate, and chloride still were much lower than the limits.

Table 2. TCLP result

\begin{tabular}{|c|c|c|c|c|c|}
\hline & \multicolumn{2}{|c|}{$\begin{array}{l}\text { Demolition waste } \\
<10 \text { years }(\mathrm{mg} / \mathrm{L})\end{array}$} & \multicolumn{2}{|c|}{$\begin{array}{l}\text { Demolition waste } \\
>10 \text { years }(\mathrm{mg} / \mathrm{L})\end{array}$} & \multirow[t]{2}{*}{ Indonesia TCLP Standard (mg/L)* } \\
\hline & Min & Max & Min & Max & \\
\hline Copper & 0.12 & 0.20 & 0.20 & 0.35 & 10.00 \\
\hline Lead & 0.52 & 0.65 & 0.42 & 0.60 & 0.50 \\
\hline Zinc & 0.47 & 0.55 & 0.8 & 0.87 & 50.00 \\
\hline Sulphate & 191.60 & 240.00 & 150.40 & 220.30 & $* *)$ \\
\hline Chloride & 24.00 & 30.00 & 20.50 & 55.00 & $12,500.00$ \\
\hline Fluoride & 1.10 & 1.50 & 2.40 & 2.75 & 75.00 \\
\hline
\end{tabular}

*) PP RI no 101/2014 Appendix IV about Standard TCLP Test

**) No limited value

Low concentration of cooper (Fig. 4) and zinc (Fig. 5) in both sample, less and more than 10 years, can be due to reduction by adsorption phenomena within the porous structure, which makes diffusion barrier between water and these elements [7]. In the site, an affinity of heavy metal with sub-surface geology, which consists of clay can cause absence of heavy metal in groundwater [13]. These kinds of heavy metals may constitute environmental problems if the leachates migrate into the groundwater. If copper in the undesirable limit on groundwater will give the effects such as astringent taste, discoloration and corrosion of pipe, fitting and utensils [14]. 


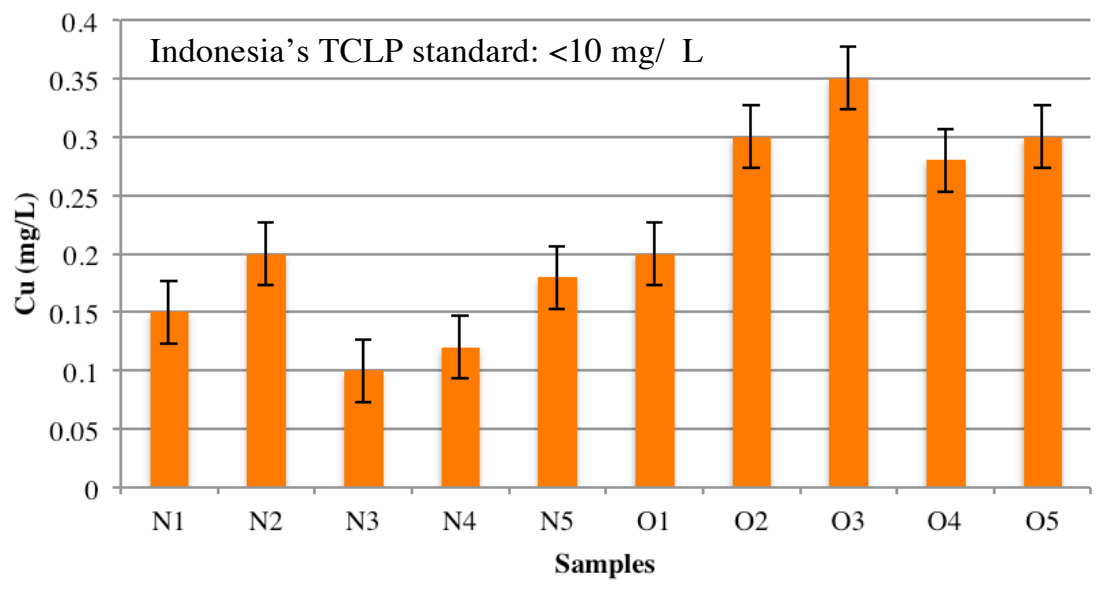

$\mathrm{N} 1$ - N5 samples from building demolition in the age $<10$ years $\mathrm{O} 1$ - O5 samples from building demolition in the age $>10$ years

Fig. 4. TCLP result of copper

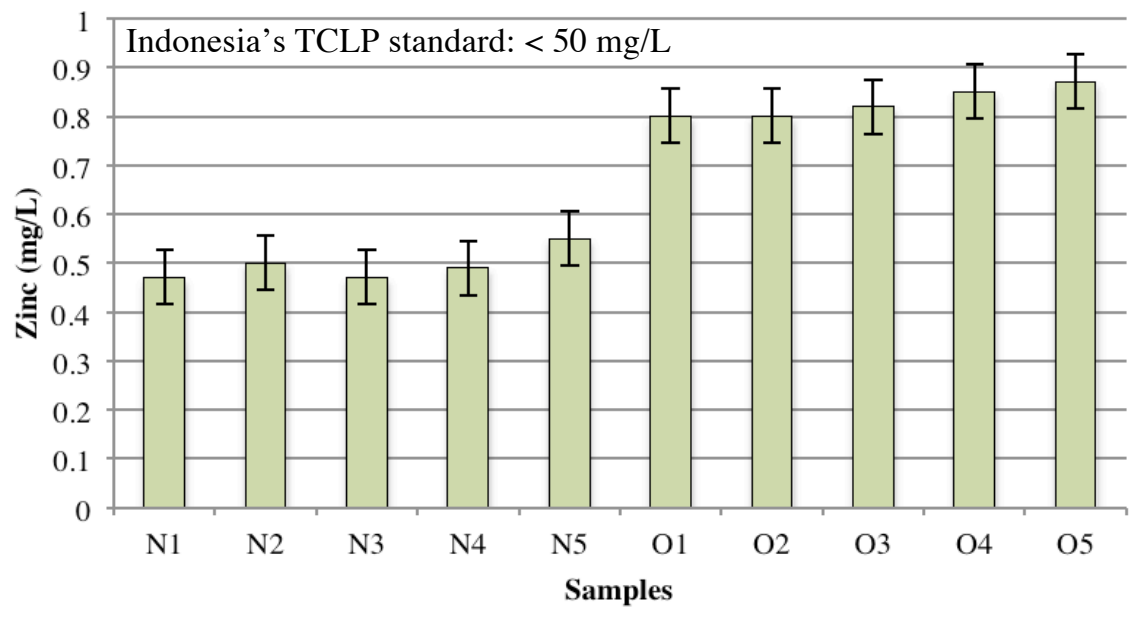

$\mathrm{N} 1$ - N5 samples from building demolition in the age $<10$ years O1 - O5 samples from building demolition in the age $>10$ years

Fig. 5. TCLP result of zinc

A concentration of lead (Fig. 6) on leachate sample of demolition waste in the age less than 10 years is higher than the limit value $(0.65 \mathrm{mg} / \mathrm{L}$ instead of $0.50 \mathrm{mg} / \mathrm{L}$ for the limit value). Lead is categorized as hazardous waste. It contain was probably came from chip plaster coated with lead-base paint. There were no significant difference values between two kinds samples, because the age of samples of more than 10 years were derived from building demolition in the age around less than 20 years. Lead was a common additive to paint prior to 1980 , even though still be found in household paint produced by industries in 
countries that have not banned the use of lead, recently. This metal is characterized as toxic for drinking water. The permissible limit of lead in drinking water is $0.05 \mathrm{mg} / \mathrm{L} \mathrm{[15],} \mathrm{which}$ leachate sample concentration was higher beyond the limit value. The high impact of lead made this heavy metal represent as environmental impact parameter units $\left(\mathrm{kg} \mathrm{Pbeq} / \mathrm{m}^{2}\right)$ within a Life Cycle Analysis of CDW [16].

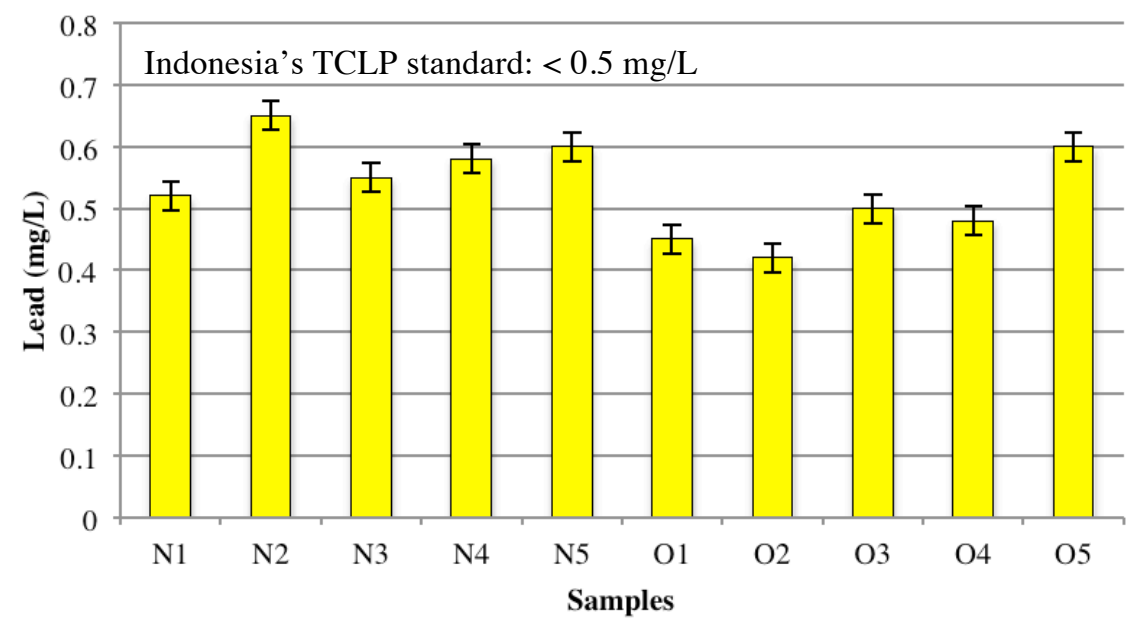

$\mathrm{N} 1$ - N5 samples from building demolition in the age $<10$ years

$\mathrm{O} 1$ - O5 samples from building demolition in the age $>10$ years

Fig. 6. TCLP result of lead

Sulphates has no limited value in Indonesia TCLP standard, but the sulphate contain have a significant leachability [7] and can be dragged away to the environment and indicate an environmental problem. Sulphate concentration is come from gypsum plaster that contained calcium sulphate, which contribute sulphate concentration in leachate. Sulphate is not considered as hazardous waste. A leachate sample of demolition waste on sulphate (Fig. 7) in the age less than 10 years and more than 10 years were 240 and $220 \mathrm{mg} / \mathrm{L}$, respectively, These values are detected higher than sulphate limit value of drinking water on $200 \mathrm{mg} / \mathrm{L}$ [15]. High concentration of sulphate in drinking water can have a laxative impact when combined with hardness elements, calcium and magnesium [14]. 


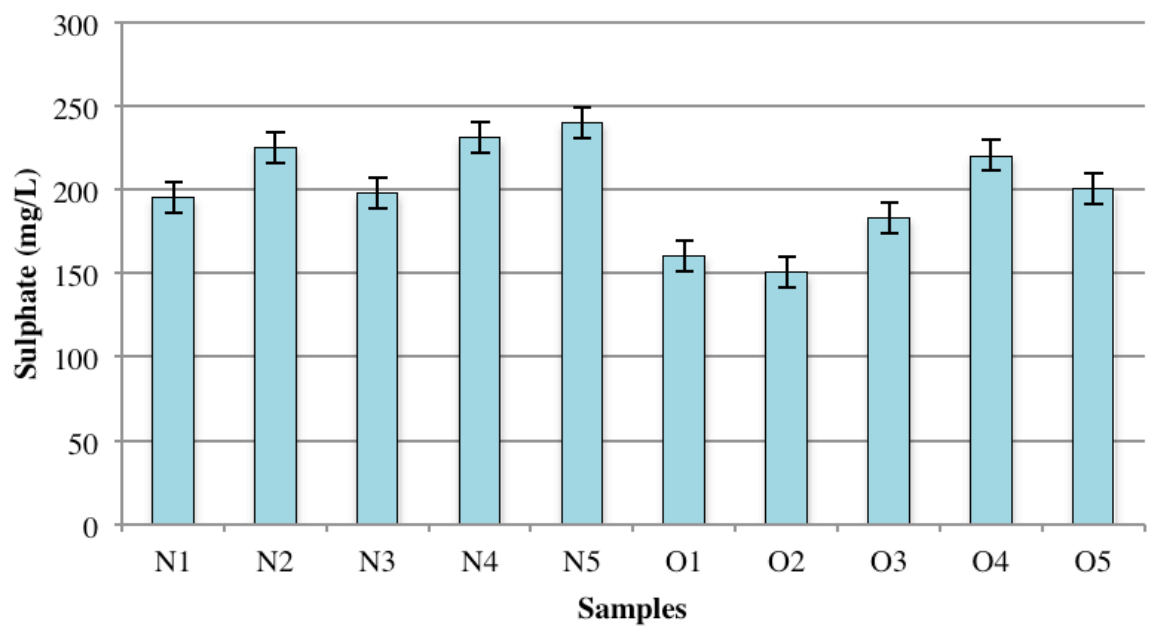

$\mathrm{N} 1$ - N5 samples from building demolition in the age $<10$ years

O1 - O5 samples from building demolition in the age $>10$ years

Fig. 7. TCLP result of sulphate

The maximum chlorides (Fig. 8) in leaching were $30 \mathrm{mg} / \mathrm{L}$ and $55 \mathrm{mg} / \mathrm{L}$ for demolition waste in the age less and more than 10 years, respectively. These values are indicating that these waste do not exposed to sea water or salts nor affected by calcium chloride that some occasion be added as hardening accelerator for concrete [17]. Chloride concentration on leaching samples did not exceed allowable limit of Indonesia TCLP $(12,500 \mathrm{mg} / \mathrm{L})$ and drinking water standards $(600 \mathrm{mg} / \mathrm{L})$.

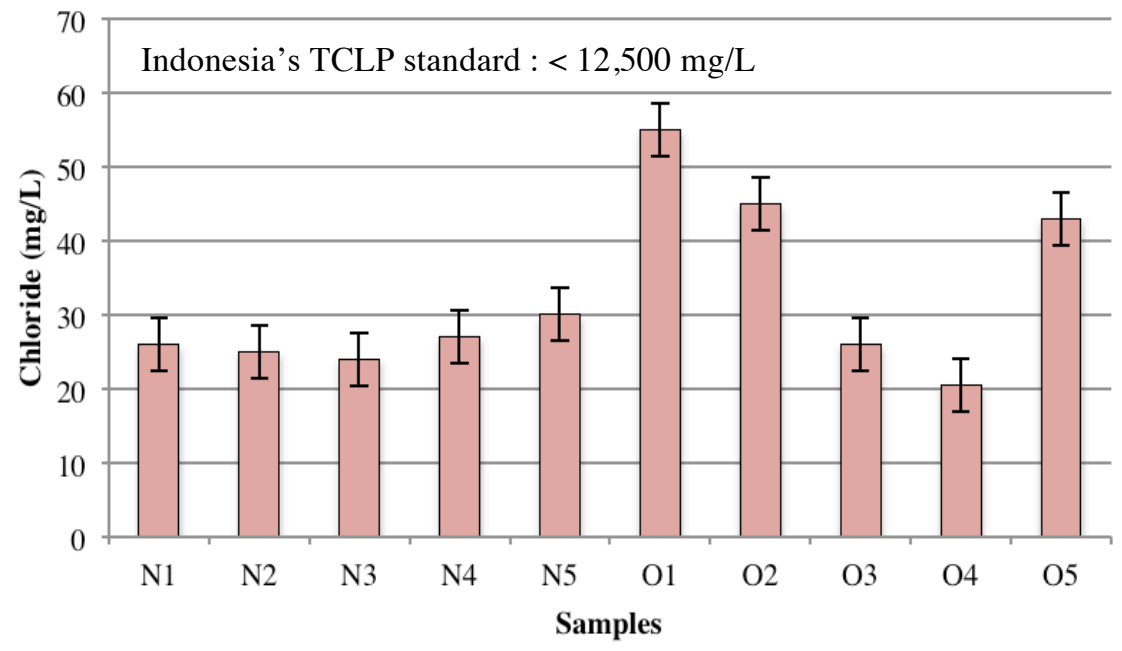

N1 - N5 samples from building demolition in the age $<10$ years

O1 - O5 samples from building demolition in the age $>10$ years

Fig. 8. TCLP result of chloride 
Flouride (Fig. 9), in the case compared with limit value of European Council Decision percolation test from previous research [7], had concentration $1.5 \mathrm{mg} / \mathrm{L}$ and $2.75 \mathrm{mg} / \mathrm{L}$ for demolition waste less and more than 10 years, respectively, that were over the limit value $(2.5 \mathrm{mg} / \mathrm{L})$. The Indonesia TCLP standard for fluoride is less strict leaching limit value on $75 \mathrm{mg} / \mathrm{L}$.

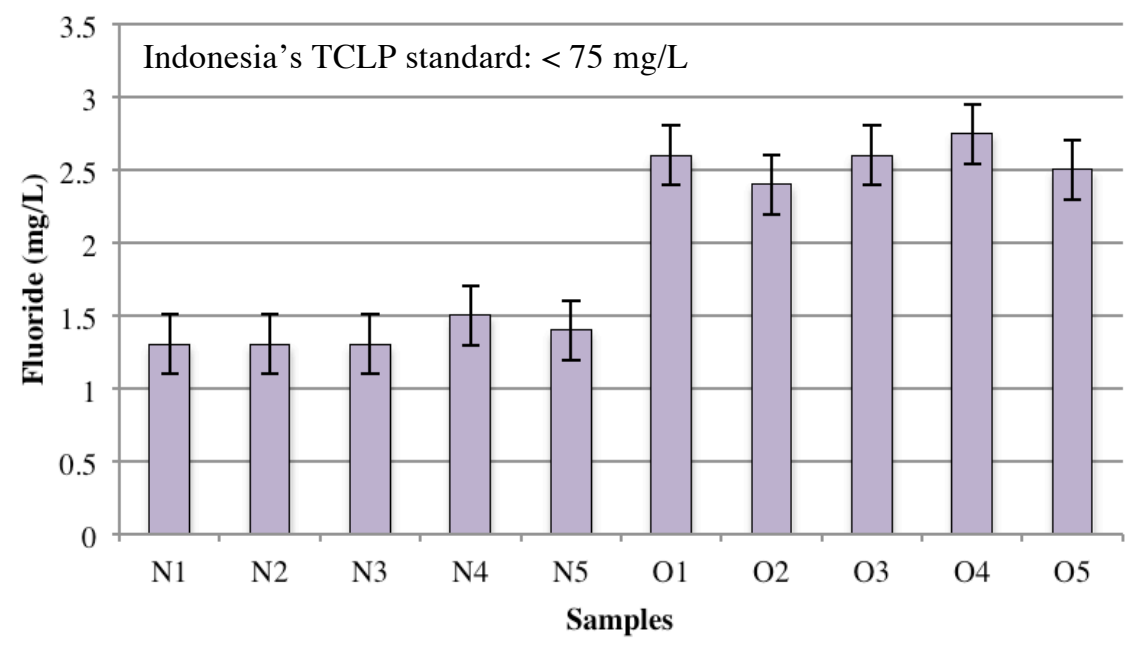

$\mathrm{N} 1$ - N5 samples from building demolition in the age $<10$ years

$\mathrm{O} 1$ - O5 samples from building demolition in the age $>10$ years

Fig. 9. TCLP result of fluoride

This preliminary result shows that leachate of demolition waste in Surabaya - Indonesia especially for cooper, zinc, sulphate, chloride and fluoride are detected on considerable level compared to Indonesia TCLP standard, excluded lead concentration. This opportune condition might be caused by kinds of material and manual sorting and crushing processes of valuable waste that can reuse or re-sale, separated from a non-valuable waste. However, in the future, the main problem for recycling demolition waste is the cost of sorting, crushing and disposal due to the manual processes [18]. A machinery process will replace manual process and implicate difficulties on sorting waste. Furthermore, a less sorting process will give more complexity on environmental impacts.

\section{Conclusions}

This preliminary research used TCLP test for demolition waste to knowing its leachate concentration. Analyses of the leachate shows that lead, as a hazardous waste, exceeded the limit value, which can cause health and environmental impacts, in particular if it is deposited in an unprotected landfill mixed with inert demolition waste. A chip plaster coated with lead-base paint, which probably lead's source, is better sorting to minimize the risk of hazardous waste in environment. A drinking water standard might be considered to realize that the impact of leachate of demolition waste could reach on soil and groundwater in environment. 


\section{References}

[1] M. R. Ponnada, Kameswari. Int. J. Adv Sci and Tech 84, 19-46 (2015)

[2] H. Yuan, L. Shen. Waste Manage 31, 670-679 (2011)

[3] A. Nugroho, T. Tongthong, T. Shin-ei. Int. J. of Civil \& Env. Eng. 13, 35-41 (2013)

[4] S. Butera, T.H. Christensen, T.F Astrup. Waste Manage 44, 196-205 (2015)

[5] M.D. Bovea, J.C. Powell. Waste Manage 50, 151-172 (2016)

[6] M. Bernardo, M.C. Gomes, J.de Brito. Waste Manage 49, 156-169 (2016)

[7] N. Roussat, J. Mehu, M. Abdelghafour, P. Brula. Waste Manage 28, 2032-2040 (2008)

[8] S. Alwi, K. Hampson, S. Mohamed. Proc. of the $1^{\text {st }}$ International Conference of CIB W107 - Creating a Sustainable Construction Industry in Developing Countries (2002)

[9] J.O.V. Trankler, I. Walker, M, Dohmann. Waste Manage 16, 21-26 (1996)

[10] Z. Wu, A.T.W Yu, L. Shen, G. Liu. Waste Manage 34, 1683-1692 (2014)

[11] A.F. Masudi, C.R. Che Hasan, N.Z. Mahmood, S.N Mokhtar, N.M. Sulaiman. Int. J. Global. Environ. 12 (2-4), 269-281 (2012)

[12] American Publich Health Association (APHA), American Water Works Association (AWWA) and Water Environment Federation (WEF) Standard method for the examination of water and wastewater. $20^{\text {th }}$ edition, American Public Health Association, Washington DC (1998)

[13] A. Adeolu O, A. Gbenga A, O. Adebayo A. African J. of Env. Sci. and Tech 5 (11), 933-940 (2011)

[14] N. Raman, D. Sathiya Narayanan. Rasayan J. Chem. 1 (4), 826-836 (2008)

[15] WHO: Guideline for Drinking Water Quality. 3rd edition. Geneva: World Health Organization; 940-949 (2008)

[16] A. Coelho, J.de Brito. Waste Manage 32, 532-541 (2012)

[17] S. Butera, T.H. Christensen, T.F Astrup. J. of Hazardous Material 276, 302-311 (2014)

[18] N. Kartam, N. Al-Mutairi, I. Al-Ghusain, J. Al-Humoud. Waste Manage 24, 10491059 (2004) 